\title{
Bax promoter G(-248)A polymorphism in a Turkish clinical breast cancer patients: A case-control study
}

\author{
Yemliha Yildiz ${ }^{1}$, Ilhan Yaylim ${ }^{1}$, Nazli Ezgi Ozkan ${ }^{1}$, Soykan Arikan $^{2}$, Saime Turan $^{1}$, Seden Kucucuk $^{3}$, \\ Ender Coskunpinar ${ }^{1}$, Turgay Isbir ${ }^{4}$ \\ ${ }^{1}$ Institute of Experimental Medicine, Department of Molecular Medicine, Istanbul University, Istanbul, Turkey \\ ${ }^{2}$ Istanbul Research and Education Hospital, Surgery Clinic, Istanbul, Turkey \\ ${ }^{3}$ Institute of Oncology, Istanbul University, Istanbul, Turkey \\ ${ }^{4}$ Institute of Health Sciences, Multidiciplinary Molecular Medicine Department, Yeditepe University, Istanbul, Turkey \\ Email: yemlihay7@yahoo.com, *ilhanyaylim@gmail.com,nzl.ezgi@gmail.com, soykanarikan@yahoo.com, \\ saimeturan86@gmail.com, sedenbraki@e-kolay.net, tisbir@superonline.com, iyaylim@,istanbul.edu.tr
}

Received 8 November 2012; revised 8 December 2102; accepted 15 December 2012

\begin{abstract}
Bax is an important protein involved in apoptotic process. Mutations of the Bax gene are known to affect protein expression and function. A promotor polymorphism G(-248)A in the 5' UTR of Bax gene may alter regulation of apoptosis in carcinogenesis. Our study was performed to test the association between $G(-248) A$ polymorphisms in the Bax gene and breast cancer risk and progression. $G(-248) A$ polymorphism was genotyped in a Turkish breast cancer, case-control population including 53 female cancer patients (mean age \pm SD: $60.9 \pm 11.9$ years) and 82 controls (mean age \pm SD: $57.2 \pm 17.5$ years) using PCR-RFLP analysis. Genotype and allele frequencies were assessed with the chi-square test. There was no difference in the distribution of Bax genotypes, and allele frequencies were $\mathbf{G}(87.7 \%$ versus $88.4 \%)$ and A $(12.3 \%$ versus $11.6 \%)$ in the cancer patients and controls, respectively. Within the cancer group, the presence of a polymorphic Bax $G(-248) A$ allele was not associated with clinico-pathological parameters such as advanced tumor stage, lymph node or distant metastasis. We present the first to report on Bax G(-248)A polymorphisms in breast cancer. Our results suggest that Bax $G(-248) A$ polymorphism do not modify individual susceptibility to invasive breast cancer in Turkish women.
\end{abstract}

Keywords: Bcl-2 Associated-X-Protein; SNP; Apoptosis; PCR; Susceptibility; Carcinogenesis

\section{INTRODUCTION}

Breast cancer is the most frequent and lethal cancer

${ }^{*}$ Corresponding author. among the women all around the world. According to statistics 226,870 women will be diagnosed as breast cancer and 39,510 deaths will be reported relevant to the disease in the US by 2012 [1]. A variety of factors play role in disease progression. Although heredity plays an important role in carcinogenesis, environmental factors, nutrition habits and somatic mutations also increase the possibility of the disease. Early diagnosis, which is specifically important for prolonged survival of the patients, has a great importance also in breast cancer as well as all other cancer types. Gene polymorphisms are known to be cancer risk detection parameters and a variety of genes which are related to increased cell proliferation and lost of apoptosis are being investigated worldwide. As all other cancers, altered apoptosis regulation is one of the major problems in breast cancer. Apoptosis in breast cancer has two different pathways. The first pathway is known as extrinsic pathway, and it is initiated by the death receptors which are the sub group of TNF receptor family [2]. In our earlier studies, we demonstrated the connection between breast cancer and polymorphisms of TNF related apoptosis inducing ligand (TRAIL) [3]. The second pathway is mitochondria centered and known as the intrinsic pathway. Regulation of this pathway is carried out by Bcl-2 family proteins that control the mitochondrial release of death factors such as cytochrome c, AIF, Smac/DIABLO and endonuclease C [4-7]. BAX $(\mathrm{Bcl}-2$ associated $\times$ protein) protein is one of the proapoptotic members of Bcl-2 family and in vivo studies in animal models and cancer cell lines demonstrate that it induces the apoptosis as a tumor suppressor [8]. Bax gene is the first defined apoptotic gene that directly activated by $\mathrm{p} 53$ [9]. This direct regulation puts a spotlight on Bax gene especially for understanding the mechanism underlying the carcinogenesis process and possible treatment approaches. 
Bax gene is located in chromosome 19q13.3 and mutations in the promoter and coding region of it are known to alter the protein expression and function thus, affecting the ability of apoptosis [10]. 50\% of human colon adenocarcinomas with the microsatellite mutator phenoltype and $20 \%$ of human hematopoetic malignancies were found to harbor Bax mutations $[11,12]$.

Bax protein has Bcl-2 homologous domains (BH1, $\mathrm{BH} 2$, $\mathrm{BH} 3$ and pseudo $\mathrm{BH} 4$ ) as other Bcl-2 family members. Among these conserved domains, $\mathrm{BH} 3$ is the most important one in the protein functions since it is known to be essential in both hetero- and homo dimerization proses and pro apoptotic ability [13-15].

Alterations in $\mathrm{BH} 1, \mathrm{BH} 3$ domains and upstream of BH3 domains were found in human malignant hematopoetic cell lines. Colorectal and gastric carcinoma with replication error positive phenotype are found to have $50 \%$ and $69 \% \mathrm{G}$ [8] alteration in $\mathrm{BH} 3$ upstream region causing the synthesis of shorten Bax protein. However, Peng et al. reported that tumor-associated mutations of bax gene are very rare events in common types of nodal and extranodal B-cell lymphomas [11,12,16-19].

In a similar aspect Bax mutations are seem to be infrequent in AIDS-NHL (Non-Hodgkin's Lymphomas) and deregulated apoptosis is not caused by Bax mutations [20]. In addition studies indicating the role of Bax mutations in cancer with microsatellite instability including colorectal cancers $[21,22]$ and gastric carcinomas $[23,24]$. Aframeshift mutation of the Bax gene in basal cell carcinoma was reported in Korean patients [25]. Beside to structural, thus functional, effects; alterations in Bax protein expression are other consequence of the mutations in Bax gene. Altered Bax protein expression has been observed in a variety of cancer [26].

Poor clinical outcome in breast carcinoma [27], nonHodgkin lymphoma [28], ovarian [29] and colon cancer [11] is shown to be related with reduced Bax expression.

Thus, mutations in the promotor region of the Bax gene are specifically taking attention. A guanine adenine substitution in 248 nucleotides upstream from the translation start point of the Bax is reported to be relevant with different conditions in different cancer types. Relation of this SNP with treatment resistance and shorter survival in chronic lymphocytic leukemia was reported [30]. In another study, $\mathrm{G}(-248) \mathrm{A}$ change was shown to reduce the gene expression [31] Influence of G(-248)A SNP in chronic lymhocytic leukemia Binet stage was also identified [32]. In a more recent research, the effect of a single nucleotide polymorphism in the bax gene promoter in transcription and cell death in retinal ganglion cells was shown in knockout mice [33]. Influence of Bax in the therapy response is also investigated in the expression levels. It was indicated that bax has the second largest influence on intrinsic cisplatin sensivity after Bcl-2
[34].

This promotor SNP has another possible importance in means of defining risk factors in cancer prediction. An elevated risk of squamous cell carcinoma of head and neck in patients having AA genotype of $\mathrm{G}(-248)$ A SNP was reported [10].

Taken together, these data suggest a key role of Bax in carcinogenesis, direct effect of the $\mathrm{G}(-248)$ A promoter polymorphism is still controversial. Regarding the lack of a study in this matter, we aimed to investigate $\mathrm{G}(-248) \mathrm{A}$ polymorphism in breast cancer.

\section{MATERIALS AND METHODS}

\subsection{Study Subjects}

Fifty-three breast cancer patients (mean age $60.9 \pm 11.9$ years) and 82 healthy females (mean age $57.2 \pm 17.5$ years) were collected between 2007 and 2011 for the study. All participants provided written informed constant prior to study. Subjects were provided from Istanbul Research and Education Hospital, Surgery Clinic and Istanbul Oncology Institute, Radiation Oncology Department. A standardized questionnaire, pathological records and medical records were received to confirm the diagnosis and cancer status. The control subjects, which were not taking any regular medication by that time, were randomly selected among volunteers. The blood samples were collected after pathological diagnosis and prior to any chemotherapeutic or radiation therapy from those patients who had not undergone blood transfusion. The study was approved by the Medical Ethics Committee of Istanbul Medical Faculty.

\subsection{Methods}

Blood sampled were collected into EDTA containing tubes. DNA was isolated from White blood cells by salting out procedure; ammonium acetate extraction and ethanol precipitation fallowing sodium dodecyl sulphatelysis and proteinase $\mathrm{K}$ digestion [35].

Promotor region of the Bax gene was amplified by using 10 pmol forward (5'-CGG GGT TAT CTC TTG GGC-3') and reverse (5'-GTG AGA GCC CCG CTG AAC-3') primers. The PCR reaction mixture contained 150 ng DNA template, $15 \mathrm{mM} \mathrm{MgCl}_{2}, 50 \mathrm{mM} \mathrm{KCl}, 10$ $\mathrm{mM}$ Tris- $\mathrm{HCl}$ (pH 8.4), $200 \mu \mathrm{M}$ each od deoxynucleotide triphosphate (MBI Fermentase, Vilnius, Lithuania) and 2 units of Taq DNA polymerase (MBI Fermentase, Vilnius, Lithuania). The DNA was denaturated at $95^{\circ} \mathrm{C}$ for 5 minutes and temperature cycling was set at $94^{\circ} \mathrm{C}$ for $30 \mathrm{sec}-$ onds, $56^{\circ} \mathrm{C}$ for 30 seconds, and $72^{\circ} \mathrm{C}$ for 45 seconds for 40 cycles, followed by a final extension at $72^{\circ} \mathrm{C}$ for 5 minutes.

438 bp PCR products were digested by AciI (MBI Fermentase, Vilnius, Lithuania) enzyme as manufacturer 
instructions. After Acil digestion, we detected two fragments having 256 and 96 bp (GG) or three fragments having 352, 256 and 96 bp (GA). Digestion of AA genotype creates a 352 bp fragment which we did not observe.

Digestion products were visualized under ultraviolet light and a photo was taken with a Polaroid camera. In case of and doubt concerning the allele, the sample was analyzed once again.

Statistical analyses were carried out using SPSS version 7.5 For Windows (SPSS Inc, Chicago, USA). Numeric values were analyzed by Student's t-test. Differences in characteristics between breast cancer patients and controls, as well as disparities in genotype and allele frequencies, were assessed with the chi-square test. Odds ratios (ORs) and 95\% confidence intervals $(95 \% \mathrm{CI})$ were calculated to estimate the risk of breast cancer. pvalues more than 0.05 were considered statistically insignificant.

\section{RESULTS}

We determined Bax $\mathrm{G}(-248)$ A polymorphism in 53 breast cancer patients and 82 controls (Figure 1). Table 1 shows the demographic and clinicopathologic data of our patients groups.

Genotypes and allele frequencies for Bax G(-248)A in breast cancer patients and controls are listed in Table 2. Genotype distributions for Bax G(-248)A polymorphism in both groups were in agreement with Hardy-Weinberg equilibrium (for controls $\chi^{2}=1.407, \mathrm{p}=0.235$; for patients $\left.\chi^{2}=1.036, \mathrm{p}=0.308\right)$. Bax $\mathrm{G}(-248)$ A genotype and allele frequencies between breast cancer patients and controls were not statistically significant $(\mathrm{p}=0.856, \mathrm{p}=$ 0.866 , respectively).

Patients with the T3/T4 stage breast cancer showed a higher prevalence of GG genotypes (91.7\%) when compared to the patients with T1/T2 stage $(70.7 \%)$. ( $\mathrm{p}=$ 0.138; OR: 1.3 ; $95 \%$ CI: 0.999 - 1.682). In the patients with capsule invasion, the frequency of AG genotype

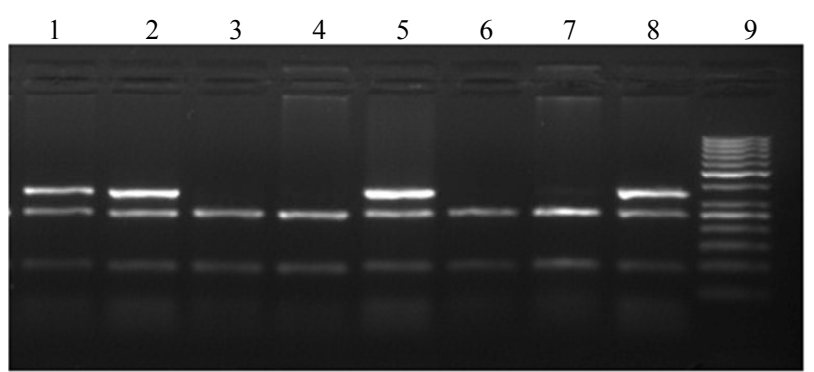

Lane 1, 2, 5 and 8: 256 bp and 96 bp fragments represents the GG phenotype. Lane 3, 4, 6 and 7: $352 \mathrm{bp}, 256 \mathrm{bp}$ and $96 \mathrm{bp}$ fragments represents GA phenotype. Lane 9: 50 bp marker.

Figure 1. Direct visualization of PCR-RFLP typing pattern of Bax G-248A genotypes by ethidium bromide staining. 438 bp PCR products were digested by AciI enzyme.
Table 1. Characteristics of patients with breast cancer ${ }^{*}$.

\begin{tabular}{|c|c|c|}
\hline Characteristic & $\mathbf{N}$ & $\%$ \\
\hline \multicolumn{3}{|l|}{ Tumor type } \\
\hline Invasive ductal carcinoma & 42 & 79.2 \\
\hline Others & 11 & 20.8 \\
\hline \multicolumn{3}{|l|}{ Age of onset (years) } \\
\hline$=<45$ & 12 & 22.6 \\
\hline$>45$ & 41 & 77.4 \\
\hline \multicolumn{3}{|l|}{ Familial history with cancer } \\
\hline Negative & 39 & 73.6 \\
\hline Positive & 14 & 26.4 \\
\hline \multicolumn{3}{|l|}{ Familial history with breast cancer } \\
\hline Negative & 42 & 79.2 \\
\hline Positive & 11 & 20.8 \\
\hline \multicolumn{3}{|l|}{ Menopausal status } \\
\hline PRE menopausal & 18 & 34 \\
\hline POST menopausal & 35 & 66 \\
\hline Absence of alcohol consumption & 53 & 100 \\
\hline Presence of smoking status & 10 & 18.9 \\
\hline \multicolumn{3}{|l|}{ Tumor stage } \\
\hline T1 & 15 & 28.3 \\
\hline $\mathbf{T} 2$ & 24 & 45.3 \\
\hline T3 & 9 & 17 \\
\hline T4 & 5 & 9.4 \\
\hline \multicolumn{3}{|l|}{ Lenf-nod metastasis } \\
\hline No & 13 & 24.5 \\
\hline N1 & 24 & 45.3 \\
\hline $\mathbf{N 2}$ & 13 & 24.4 \\
\hline N3 & 3 & 5.7 \\
\hline Presence of distant metastasis (M1) & 2 & 3.8 \\
\hline \multicolumn{3}{|l|}{ Differentiation } \\
\hline Low & 20 & 43.5 \\
\hline Medium & 23 & 50 \\
\hline High & 3 & 6.5 \\
\hline \multicolumn{3}{|l|}{ Estrogen receptor } \\
\hline Positive & 39 & 84.8 \\
\hline Negative & 7 & 15.2 \\
\hline \multicolumn{3}{|l|}{ Progesterone receptor } \\
\hline Positive & 36 & 78.3 \\
\hline Negative & 10 & 21.7 \\
\hline Presence of capsule invasion & 25 & 47.2 \\
\hline Presence of periganglionar invasion & 23 & 43.4 \\
\hline Presence of angiolymphatic invasion & 31 & 58.5 \\
\hline
\end{tabular}

${ }^{*}$ The pathological data about estrogen and progesterone status of 7 patients are absent. 
$(32 \%)$ was higher than those without capsule invasion $(17.9 \%)$, however the difference was not statistically significant $(\mathrm{p}=0.232$; OR: 1.792 ; 95\% CI: 0.674 4.768). We observed that two of the fifty-three patient, who has distant metastasis, both have the GG genotypes. In patients with angiolymphatic invasion, GG genotype frequency $(83.9 \%)$ was higher than in patients without vascular invasion (63.6) but this is not statistically significant $(\mathrm{p}=0.092)$. Distributions of Bax $\mathrm{G}(-248) \mathrm{A}$ genotypes according to clinical parameters and tumor characteristics of breast cancer patients are summarized in Table 3. Among breast cancer patients, there were no

Table 2. Genotypes and allele frequencies for Bax G(-248)A in breast patients and controls.

\begin{tabular}{|c|c|c|c|c|c|c|}
\hline Genotype & Patients $n=53$ & $\%$ & Controls $n=82$ & $\%$ & ${ }^{\#}$ OR $(95 \% \mathrm{Cl})$ & ${ }^{*} p$ value \\
\hline GG & 40 & 75.5 & 63 & 76.8 & $0.982(0.809-1.193)$ & 0.856 \\
\hline GA & 13 & 24.5 & 19 & 23.2 & $1.059(0.572-1.958)$ & 0.856 \\
\hline $\mathbf{A A}$ & 0 & 0 & 0 & 0 & - & - \\
\hline \multicolumn{7}{|c|}{ Alleles } \\
\hline G & 93 & 87.7 & 145 & 88.4 & & 0.866 \\
\hline $\mathbf{A}$ & 13 & 12.3 & 19 & 11.6 & & \\
\hline
\end{tabular}

${ }^{*}$ p-value was obtained by chi-square test. ${ }^{*}$ Odds ratio for genotype was calculated as selected genotype $v s$. Other genotypes. OR indicates crude odds ratio.

Table 3. Distribution of Bax (G-248)A genotypes with clinicopathological features in breast cancer patients*.

\begin{tabular}{|c|c|c|c|c|}
\hline Histopathological parameters & $\mathbf{N}$ & $\%$ & GG (\%) & GA $(\%)$ \\
\hline \multicolumn{5}{|l|}{ Tumor stage } \\
\hline T1, T2 & 41 & 77.3 & $29(70.7)$ & $12(29.3)$ \\
\hline T3, T4 & 12 & 22.7 & $11(91.7)$ & $1(8.3)$ \\
\hline \multicolumn{5}{|l|}{ Lyph node status } \\
\hline $\mathbf{N}(+)$ & 37 & 69.8 & $27(73)$ & $10(27)$ \\
\hline $\mathbf{N}(-)$ & 16 & 30.2 & $13(81.3)$ & $3(18.8)$ \\
\hline \multicolumn{5}{|l|}{ Distant metastasis } \\
\hline $\mathbf{M}(+)$ & 2 & 3.8 & $2(100)$ & 0 \\
\hline $\mathbf{M}(-)$ & 51 & 96.2 & $38(74.5)$ & $13(25.5)$ \\
\hline \multicolumn{5}{|l|}{ Oestrogen receptor } \\
\hline Negative & 7 & 15.2 & $5(71.4)$ & $2(28.6)$ \\
\hline Positive & 39 & 84.8 & $28(71.8)$ & $11(28.2)$ \\
\hline \multicolumn{5}{|l|}{ Progesterone receptor } \\
\hline Negative & 10 & 21.7 & $6(60)$ & $4(40)$ \\
\hline Positive & 36 & 78.3 & $27(75)$ & $9(25)$ \\
\hline \multicolumn{5}{|l|}{ Capsule invasion } \\
\hline Negative & 28 & 52.8 & $23(82.1)$ & $5(17.9)$ \\
\hline Positive & 25 & 47.2 & $17(68)$ & $8(32)$ \\
\hline \multicolumn{5}{|l|}{ Periganglionar invasion } \\
\hline Negative & 30 & 56.6 & $22(73.3)$ & $8(26.7)$ \\
\hline Positive & 23 & 43.4 & $18(78.3)$ & $5(21.7)$ \\
\hline \multicolumn{5}{|l|}{ Angiolymphatic invasion } \\
\hline Negative & 22 & 41.5 & $14(63.6)$ & $8(36.4)$ \\
\hline Positive & 31 & 58.5 & $26(83.9)$ & $5(16.1)$ \\
\hline \multicolumn{5}{|l|}{ Differentiation } \\
\hline Low & 20 & 43.5 & $15(75)$ & $5(25)$ \\
\hline High & 26 & 56.5 & $19(73.1)$ & $7(26.9)$ \\
\hline
\end{tabular}

\footnotetext{
${ }^{*}$ AA genotype was not detected in study groups.
} 
significant association between the Bax G(-248)A genotypes and some clinical parameters including age at diagnosis, family history, menopausal status, smoking, using alcohol and some pathological parameters such as tumor stage, lymph node metastasis, distant metastasis, periganglionar invasion, estrogen and progesterone receptor status and also tumor differentiation (data are not shown).

\section{DISCUSSION}

Bax gene which is a member of Bcl-2 family is an important regulator of apoptosis. Although altered expression of Bax protein seems to be more relevant with carcinogenesis process, mutations leading this disregulation and correlations of these mutations with different cancers are hotspots among the researchers. Promotor region of the Bax gene contains p53 response elements thus affects gene expression [31].

Different mutations of Bax gene have been examined in different studies so far. Saxana et al. defined the G(-248)A SNP in chronic lymphocytic leukemia (CLL) in 2002 and suggested a relation between disease progression and treatment resistance with 34 patients [30]. In control group, genotypic frequencies were $94.3 \%$ and $5.7 \%$ for GG and GA genotypes; and allelic frequencies were 0.97 and 0.03 for $\mathrm{G}$ and $\mathrm{A}$ alleles respectively. Although the differences in distribution of alleles; absence of AA genotype neither in control nor in patient group, supports our findings.

In a more recent study, Skogsberg et al. used a bigger study group (463 cases and 207 controls) and found no significant differences between Bax G(-248)A polymerphism and CLL progression or treatment resistant [36]. Genotyping frequencies in control group were 79\%, 19\% and $2 \%$ for GG, GA and AA genotypes respectively, again indicating a rare presence of A allele. These results are highly relevant to our findings $(76.8 \% \mathrm{GG}, 23.2 \%$ GA, $0 \%$ AA; $n=82$ ) if we consider the number of subjects that has been examined. It is possible to get more similar results with a higher number of subject.

In this study, we did not record a statistically significant difference in Bax G(-248)A genotype and allele frequencies between breast cancer patients and control. However we observed that some of the clinic-pathological data may be related with specific genotypes.

GG genotype frequency $(83.9 \%)$ was higher in patients with angiolymphatic invasion when compared to those without $(63.6 \%)$. These results suggest that GG genotype in the Bax promoter region may increase angiolymphatic invasion in breast cancer and consequently increase metastatic spread and be an adverse prognostic factor.

A similar relationship was also observed in patients carrying the Bax AG genotype, with 1.79 fold increased risk for capsule invasion. Capsular invasion at metastatic nodes in breast cancer was shown to be strongly associated with further regional nodes metastasis [37,38]. Thus, such a possible increased risk may be related to breast cancer progression, specifically in later stages of the disease.

This paper represents the first study on Bax G(-245)A polymorphism in breast cancer and gives an opinion about the possible effects of this polymorphism in breast cancer progression. However further validations in larger studies are needed to clarify the role of $\mathrm{G}(-248)$ A polymorphism in breast cancer.

\section{ACKNOWLEDGEMENTS}

This study was supported by a grant from Istanbul University, Research Foundation (project number: 1715), Turkey.

\section{REFERENCES}

[1] Siegel, R., Naishadham, D. and Jemal, A. (2012) Cancer statistics. CA: A Cancer Journal for Clinicians, 62, 10-29. doi: $10.3322 /$ caac. 20138

[2] Ashkenazi, A. and Dixit, V.M. (1998) Death receptors: Signaling and modulation. Science, 281, 1305-1308. doi:10.1126/science.281.5381.1305

[3] Yildiz, Y., Yaylim-Eraltan, I., Arikan, S., Ergen, H.A., Küçücük, S. and Isbir, T. (2010) Is there any correlation between TNF-related apoptosis-inducing ligand (TRAIL) genetic variants and breast cancer? Archives of Medical Science, 6, 932-936. doi:10.5114/aoms.2010.19304

[4] Susin, S.A., Lorenzo, H.K., Zamzami, N., Marzo, I., Snow, B.E., Brothers, G.M., Mangion, J., Jacotot, E., Costantini, P., Loeffler, M., Larochette, N., Goodlett, D.R., Aebersold, R., Siderovski, D.P., Penninger, J.M. and Kroemer, G. (1999) Molecular characterization of mitochondrial apoptosis-inducing factor. Nature, 397, 441-446. doi:10.1038/17135

[5] Du, C., Fang, M., Li, Y., Li, L. and Wang, X. (2000) Smac, a mitochondrial protein that promotes cytochrome c-dependent caspase activation by eliminating IAP inhibition. Cell, 102, 33-42. doi:10.1016/S0092-8674(00)00008-8

[6] Verhagen, A.M., Ekert, P.G., Pakusch, M., Silke, J., Connolly, L.M., Reid, G.E., Moritz, R.L., Simpson, R.J. and Vaux, D.L. (2000) Identification of DIABLO, a mammalian protein that promotes apoptosis by binding to and antagonizing IAP proteins. Cell, 102, 43-53. doi:10.1016/S0092-8674(00)00009-X

[7] Li, K., Li, Y., Shelton, J.M., Richardson, J.A., Spencer, E., Chen, Z.J., Wang, X. and Williams, R.S. (2000) Cytochrome c deficiency causes embryonic lethality and attenuates stress-induced apoptosis. Cell, 101, 389-399. doi:10.1016/S0092-8674(00)80849-1

[8] Zhang, L., Yu, J., Park, B.H., Kinzler, K.W. and Vogelstein, B. (2000) Role of BAX in the apoptotic response to anticancer agents. Science, 290, 989-992. 
doi:10.1126/science.290.5493.989

[9] Miyashita, T. and Reed, J.C. (1995) Tumor suppressor p53 is a direct transcriptional activator of the human bax gene. Cell, 80, 293-299. doi:10.1016/0092-8674(95)90412-3

[10] Chen, K., Hu, Z., Wang, L.E., Sturgis, E.M., El-Naggar, A.K., Zhang, W. and Wei, Q. (2007) Single-nucleotide polymorphisms at the TP53-binding or responsive promoter regions of BAX and BCL2 genes and risk of squamous cell carcinoma of the head and neck. Carcino- genesis, 28, 2008-2012. doi:10.1093/carcin/bgm172

[11] Rampino, N., Yamamoto, H., Ionov, Y., Li, Y., Sawai, H., Reed, J.C. and Perucho, M. (1997) Somatic frameshift mutations in the BAX gene in colon cancers of the microsatellite mutator phenotype. Science, 275, 967-969. doi:10.1126/science.275.5302.967

[12] Meijerink, J.P., Mensink, E.J., Wang, K., Sedlak, T.W., Slöetjes, A.W., de Witte, T., Waksman, G. and Korsmeyer, S.J. (1998) Hematopoietic malignancies demonstrate loss-of-function mutations of BAX. Blood, 91, 2991-2997.

[13] Adams, J.M. and Cory, S. (1998) The Bcl-2 protein family: Arbiters of cell survival. Science, 281, 1322-1326. doi:10.1126/science.281.5381.1322

[14] Yin, X.M., Oltvai, Z.N. and Korsmeyer, S.J. (1994) BH1 and $\mathrm{BH} 2$ domains of $\mathrm{Bcl}-2$ are required for inhibition of apoptosis and heterodimerization with Bax. Nature, 369, 321-323. doi:10.1038/369321a0

[15] Zha, H., Aimé-Sempé, C., Sato, T. and Reed, J.C. (1996) Proapoptotic protein Bax heterodimerizes with $\mathrm{Bcl}-2$ and homodimerizes with Bax via a novel domain (BH3) distinct from $\mathrm{BH} 1$ and $\mathrm{BH} 2$. The Journal of Biological Chemistry, 271, 7440-7444. doi:10.1074/jbc.271.13.7440

[16] Peng, H., Aiello, A., Packham, G., Isaacson, P.G. and Pan, L. (1998) Infrequent bax gene mutations in B-cell lymphomas. The Journal of Pathology, 186, 378-382. doi:10.1002/(SICI)1096-9896(199812)186:4<378::AID-P ATH203>3.0.CO;2-5

[17] Meijerink, J.P., Smetsers, T.F., Slöetjes, A.W., Linders, E.H. and Mensink, E.J. (1995) Bax mutations in cell lines derived from hematological malignancies. Leukemia, 9, 1828-1832.

[18] Yamamoto, H., Sawai, H. and Perucho, M. (1997) Frameshift somatic mutations in gastrointestinal cancer of the microsatellite mutator phenotype. Cancer Reserch, 57, 4420-4426.

[19] Brimmell, M., Mendiola, R., Mangion, J. and Packham, G. (1998) BAX frameshift mutations in cell lines derived from human haemopoietic malignancies are associated with resistance to apoptosis and microsatellite instability. Oncogene, 16, 1803-1812. doi:10.1038/sj.onc.1201704

[20] Gaidano, G., Vivenza, D., Forconi, F., Capello, D., Gloghini, A., Bhatia, K., Gutierrez, M., Gallicchio, M., Avanzi, G.C., Fassone, L., Ariatti, C., Buonaiuto, D., Cingolani, A., Saglio, G., Tirelli, U., Larocca, L.M., DallaFavera, R. and Carbone, A. (2000) Mutation of BAX occurs infrequently in acquired immunodeficiency syndrome-related non-Hodgkin's lymphomas. Genes Chromosomes Cancer, 27, 177-182.
doi:10.1002/(SICI)1098-2264(200002)27:2<177::AID-G CC9>3.0.CO;2-O

[21] Yashiro, M., Hirakawa, K. and Boland, C.R. (2010) Mutations in TGFbeta-RII and BAX mediate tumor progression in the later stages of colorectal cancer with microsatellite instability. BMC Cancer, 10, 303. doi:10.1186/1471-2407-10-303

[22] Shima, K., Morikawa, T., Yamauchi, M., Kuchiba, A., Imamura, Y., Liao, X., Meyerhardt, J.A., Fuchs, C.S. and Ogino, S. (2011) TGFBR2 and BAX mononucleotide tract mutations, microsatellite instability, and prognosis in 1072 colorectal cancers. PLoS One, 6, e25062. doi:10.1371/journal.pone.0025062

[23] Oliveira, C., Seruca, R., Seixas, M. and Sobrinho-Simões, M. (1998) The clinicopathological features of gastric carcinomas with microsatellite instability may be mediated by mutations of different "target genes": A study of the TGFbeta RII, IGFII R, and BAX genes. The American Journal of Pathology, 153, 1211-1219. doi:10.1016/S0002-9440(10)65665-9

[24] Iacopetta, B.J., Soong, R., House, A.K. and Hamelin, R. (1999) Gastric carcinomas with microsatellite instability: Clinical features and mutations to the TGF-beta type II receptor, IGFII receptor, and BAX genes. The Journal of Pathology, 187, 428-432. doi:10.1002/(SICI)1096-9896(199903)187:4<428::AID-P ATH264>3.0.CO;2-A

[25] Cho, S., Hahm, J.H. and Hong, Y.S. (2001) Analysis of p53 and BAX mutations, loss of heterozygosity, p53 and BCL2 expression and apoptosis in basal cell carcinoma in Korean patients. British Journal of Dermatology, 144, 841-848. doi:10.1046/j.1365-2133.2001.04142.x

[26] Addeo, R., Crisci, S., D’Angelo, V., Vincenzi, B., Casale, F., Pettinato, G., Donofrio, V., Boldrini, R., Alaggio, R., Collini, P., Bertorelle, R., Di Tullio, M.T., Caraglia, M., Terenziani, M., Lo Curto, M. and Indolfi, P. (2007) Bax mutation and overexpression inversely correlate with immature phenotype and prognosis of childhood germ cell tumors. Oncology Reports, 17, 1155-1161.

[27] Krajewski, S., Blomqvist, C., Franssila, K., Krajewska, M., Wasenius, V.M., Niskanen, E., Nordling, S. and Reed, J.C. (1995) Reduced expression of proapoptotic gene $\mathrm{BAX}$ is associated with poor response rates to combination chemotherapy and shorter survival in women with metastatic breast adenocarcinoma. Cancer Reserch, 55, 4471-4478.

[28] Gascoyne, R.D., Krajewska, M., Krajewski, S., Connors, J.M. and Reed, J.C. (1997) Prognostic significance of Bax protein expression in diffuse aggressive non-Hodgkin's lymphoma. Blood, 90, 3173-3178.

[29] Tai, Y.T., Lee, S., Niloff, E., Weisman, C., Strobel, T. and Cannistra, S.A. (1998) BAX protein expression and clinical outcome in epithelial ovarian cancer. Journal of Clinical Oncology, 16, 2583-2590.

[30] Saxena, A., Moshynska, O., Sankaran, K., Viswanathan, S. and Sheridan, D.P. (2002) Association of a novel single nucleotide polymorphism, G(-248)A, in the 5'UTR of BAX gene in chronic lymphocytic leukemia with disease progression and treatment resistance. Cancer Letters, 187, 199-205. 


\section{doi:10.1016/S0304-3835(02)00378-6}

[31] Moshynska, O., Moshynskyy, I., Misra, V. and Saxena, A. (2005) G125A single nucleotide polymorphism in the human BAX promoter affects gene expression. Oncogene, 24, 2042-2049. doi:10.1038/sj.onc. 1208377

[32] Lahiri, O., Harris, S., Packham, G. and Howell, M. (2007) p53 pathway gene single nucleotide polymorphisms and chronic lymphocytic leukemia. Cancer Genetics and Cytogenetics, 179, 36-44. doi:10.1016/j.cancergencyto.2007.07.013

[33] Semaan, S.J., Li, Y. and Nickells, R.W. (2010) A single nucleotide polymorphism in the Bax gene promoter affects transcription and influences retinal ganglion cell death. ASN Neuro, 2, e00032. doi:10.1042/AN20100003

[34] Farnebo, L., Jedlinski, A., Ansell, A., Vainikka, L., Thunell, L.K., Grénman, R., Johansson, A.C. and Roberg, K. (2009) Proteins and single nucleotide polymorphisms involved in apoptosis, growth control, and DNA repair predict cisplatin sensitivity in head and neck cancer cell lines. International Journal of Molecular Medicine, 24, 549556.

[35] Miller, S.A., Dykes, D.D. and Polesky, H.F. (1988) A simple salting out procedure for extracting DNA from human nucleated cells. Nucleic Acids Research, 16, 1215. doi:10.1093/nar/16.3.1215

[36] Skogsberg, S., Tobin, G., Kröber, A., Kienle, D., Thunberg, U., Aleskog, A., Karlsson, K., Laurell, A., Merup, M., Vilpo, J., Sundström, C., Roos, G., Jernberg-Wiklund, H., Döhner, H., Nilsson, K., Stilgenbauer, S. and Rosenquist, R. (2006) The G(-248)A polymorphism in the promoter region of the Bax gene does not correlate with prognostic markers or overall survival in chronic lymphocytic leukemia. Leukemia, 20, 77-81. doi:10.1038/sj.leu.2404030

[37] Fujii, T., Tabe, Y., Yajima, R., Yamaguchi, S., Tsutsumi, S., Asao, T. and Kuwano, H. (2011) Extracapsular invasion as a risk factor for disease recurrence in colorectal cancer. World Journal of Gastroenterology, 17, 20032006. doi:10.3748/wjg.v17.i15.2003

[38] Fujii, T., Yanagita, Y., Fujisawa, T., Hirakata, T., Iijima, M. and Kuwano, H. (2010) Implication of extracapsular invasion of sentinel lymph nodes in breast cancer: Prediction of nonsentinel lymph node metastasis. World Journal of Surgery, 34, 544-548. doi:10.1007/s00268-009-0389-4 